\title{
NERVE GROWTH FACTOR-TREATED, NEURITE-BEARING PC12 CELLS CONTINUE TO SYNTHESIZE DNA ${ }^{1}$
}

\author{
MICHAEL J. IGNATIUS, ${ }^{2}$ CHARLES R. CHANDLER, ${ }^{*}$ AND ERIC M. SHOOTER \\ Department of Neurobiology, Stanford University School of Medicine, Stanford, California 94305 and ${ }^{*}$ Pfizer General Research, \\ Groton, Connecticut 06340
}

Received February 2, 1984; Revised July 13, 1984; Accepted July 19, 1984

\begin{abstract}
Cultures of rat pheochromocytoma (PC12) cells treated with $\beta$-nerve growth factor (NGF) for up to 15 days continue to synthesize DNA. The present study (1) compares the extent of maintained DNA synthesis in cells with and without processes and (2) asks whether the observed DNA synthesis in differentiated PC12 cells reflects either the continued division of the cells or the formation of polyploid cells, or both. PC12 cells were grown on tissue coverslips for various lengths of time with or without $50 \mathrm{ng} / \mathrm{ml}$ of $\beta$-NGF and then assayed for DNA synthesis by $\left[{ }^{3} \mathrm{H}\right]$ thymidine labeling and autoradiography. In 8-day-old control cultures (no NGF), 30\% of the cells had labeled nuclei after a 2 -hr $\left[{ }^{3} \mathrm{H}\right]$ thymidine pulse. In contrast, in cultures treated for 8 days with NGF, only $7 \%$ of the cells were labeled (i.e., still synthesizing DNA). The fractions of process-bearing and nonprocess-bearing cells with labeled nuclei were identical. Even after 14 days in NGF, $7 \%$ of the cells with neurites were still synthesizing DNA during any 2 -hr period. With continuous $\left[{ }^{3} \mathrm{H}\right]$ thymidine labeling in the presence of NGF from 8 to 13 days, nearly $70 \%$ of the cells with neurites were labeled. The presence of neurites induced by NGF does not preclude continued (albeit reduced) DNA synthesis in these PC12 cells.

To determine the fate of this newly synthesized DNA, nuclei extracted from NGF-treated PC12 cells were analyzed for the cellular distribution of DNA by combined propidium iodine staining and flow microfluorimetry. NGF treatment resulted in a 3 -fold increase in the number of $\mathrm{G}_{2}+\mathrm{M} / 4 \mathrm{~N}$ cells along with the appearance of $8 \mathrm{~N}$ cells. We conclude that NGF slows DNA synthesis but does not stop it, as was previously believed, and that mitotic activity can persist in morphologically differentiated PC12 cells.
\end{abstract}

The developing vertebrate peripheral nervous system must undergo a series of precisely controlled transitions from proliferative migrating neuroblasts to mature postmitotic clusters or ganglia of nerve cells. The synchrony with which this occurs probably results from a temporally sequenced set of interactions hetween the migrating cells and their environment. One agent thought to play a role in these interactions is nerve growth factor (NGF), a polypeptide that has been shown to play a pivotal role in the survival and development of some neural crest-derived tissues, including sensory and sympathetic neurons along with cells in the adrenal medulla. The requirement of NGF for the survival of embryonic rat, mouse, and chick ganglia at various stages of development is a well documented phenomenon (see Thoenen and Barde, 1980, for review). In addition to maintaining these cells, NGF may also stimulate

\footnotetext{
${ }^{1}$ We wish to thank the late Dr. Henry Kaplan and Dan Percy for contributing their time and for the use of their fluorescence-activated cell sorter analyzer. We are also indebted to Peter W. Gunning who prompted and encouraged the current study. This work was supported by National Institute of Neurological and Communicative Disorders and Stroke Grant NS-04270 and American Cancer Society Grant BC325. M. J. I. was supported by Neurosciences Training Program Grant MH-17047, and C. E. C. had a fellowship from the Muscular Dystrophy Association and the National Amyotrophic Lateral Sclerosis Foundation.

${ }^{2}$ To whom correspondence should be addressed.
}

their differentiation from migratory, proliferating neuroblasts into mature, mitotically quiescent neurons.

Recently, a cell line (PC12) derived from a rat pheochromocytoma has been developed, which is responsive to NGF (Greene and Tischler, 1976: Dichter et al., 1977). As with sympathetic and sensory neurons, nanomolar concentrations of NGF will stimulate extensive neurite outgrowth in PC12 cells. Unlike 8-day-old sensory and sympathetic ganglia, PC12 cells are still dividing, do not require NGF' for their survival in culture, and have not had recent exposure to NGF. As such, they are an excellent model for documenting the effects of NGF on an undifferentiated and dividing population of neuroblasts.

In the original characterization of NGF's effect on PC12 cells, besides the induction of electrically excitable neurites, increases in the specific activities of certain transmitter enzymes (Dichter et al., 1977; Schubert et al., 1977; Hatanaka et al., 1978), and the induction of a limited number of proteins (Garrels and Schubert, 1979), NGF was also thought to block cell proliferation as determined from growth curves (Greene, 1978). It was concluded that NGF, in addition to inducing PC12 differentiation, also removes PC12 cells from the cell cycle (Greene, 1978). However, recent work by Gunning et al. (1981) and Goodman et al. (1979) challenges the notion that NGF completely blocks cell division in PC12 cells. These studies demonstrated that DNA synthesis continues in cultures treated with NGF for as long as 10 days. Moreover, autoradiographs showed $\left[{ }^{3} \mathrm{H}\right]$ thymidine incorporation, representing DNA syn- 
thesis, in neurite-bearing cells even after 10 days in NGF (Gunning et al., 1981).

Incorporation of $\left[{ }^{3} \mathrm{H}\right]$ thymidine can represent a variety of cellular events in addition to normal cellular division. Included among these are DNA repair, the filling of intracellular precusor pools, formation of polyploid or binucleate cells, and even the partial duplication or amplification of the genome. The present study was aimed at resolving which of these possibilities occurs in neurite-bearing as well as neurite-free, NGF-induced PC12 cells.

Our studies show that NGF treatment slows but does not stop DNA synthesis in neurite-bearing and neurite-free ("nonresponding") $\mathrm{PC} 12$ cells. The persistent $\left[{ }^{3} \mathrm{H}\right]$ thymidine incorporation represents successive duplication of the cell's genome, which in most instances results in the formation of nonmultinucleate, polyploid neurons. Our data also suggest that at least some of the NGF-treated cells continue to divide.

\section{Materials and Methods}

Conditions for cell growth and induction. A rat pheochromocytoma clone (PC12) was obtained from D. Schubert (Salk Institute, San Diego, CA). The cells were grown on polystyrene tissue culture dishes (Nunc) in Dulbecco's modified Eagle's medium containing $10 \%$ fetal calf serum $(\mathrm{v} / \mathrm{v})$ and $5 \%$ horse serum (v/v) (Irvine Scientific, Santa Ana, CA) in a water saturated atmosphere of $88 \%$ air, $12 \% \mathrm{CO}_{2}$. Induction of neurites with $\beta$-NGF (prepared by the method of Smith et al., 1968) was performed by replating cells onto poly-L-lysine (type IV, Sigma)coated $(1 \mathrm{mg} / \mathrm{ml}, 60 \mathrm{~min})$ polystyrene coverslips (Lux) in multiwell culture dishes (Lux). Cells were plated at a density of $2.5 \times 10^{3}$ cells/ $\mathrm{cm}^{2}$ to minimize crowding of processes and cell bodies. Unless otherwise specified, cells were allowed to reach log phase growth (3 days), and then fresh medium with $100 \mathrm{ng} / \mathrm{ml}$ of $\beta$-NGF was added. $\beta$-NGF (100 $\mathrm{ng} / \mathrm{ml}$ final concentration) was added with or without medium changes every 2 days after the first addition.

$\left[{ }^{3} H\right]$ Thymidine incorporation. Tritiated thymidine incorporation was measured as follows. [N-methyl ${ }^{3} \mathrm{H}$ ]Thymidine $(2 \mu \mathrm{Ci} / \mathrm{ml}, 10$ to 20 $\mathrm{Ci} / \mathrm{mM}$; New England Nuclear, Boston, MA) was added to cultures for various lengths of time. Cells were then washed three times $(5 \mathrm{ml}$ for 1 min each) with unlabeled $10 \mathrm{~mm}$ thymidine in phosphate-buffered saline with $1 \mathrm{mg} / \mathrm{ml}$ of glucose (PBG) and fixed overnight with $1 \%$ paraformaldehyde, $2 \%$ glutaraldehyde, and $5 \%$ sucrose in distilled water $\left(\mathrm{DH}_{2} \mathrm{O}\right)$. On the following day, the fixed cells on the coverslips were washed three times with $\mathrm{PBG}$ and twice with $\mathrm{DH}_{2} \mathrm{O}$ before dipping in emulsion.

Autoradiographic procedures were essentially those described by Kopriwa and Leblond (1962). Kodak NTB2 nuclear track emulsion was diluted $1: 1$ with $\mathrm{DH}_{2} \mathrm{O}$ at $37^{\circ} \mathrm{C}$. Coverslips with their overlay of cells were dipped and allowed to dry before being left to expose at $4^{\circ} \mathrm{C}$ for 14 days in the dark. The exposed coverslips were developed in Kodak D-19 developer for $2 \min$ at $21^{\circ} \mathrm{C}$, washed for 15 sec in $\mathrm{DH}_{2} \mathrm{O}$, fixed in Kodak Rapid Fixer for 2 min, and washed with filtered $\mathrm{DH}_{2} \mathrm{O}$ for $15 \mathrm{~min}$. The air-dried coverslips were mounted on glass slides with $50 \%$ glycerine $(\mathrm{v} / \mathrm{v})$ in $\mathrm{DH}_{2} \mathrm{O}$.

Scoring the cells. The cells on the developed and mounted coverslips were viewed with phase optics at $\times 200$ to 400 magnification, and cells were scored as either differentiated or undifferentiated as well as labeled or unlabeled. Differentiated cells were defined as cells with neurites at least two cell body diameters $(\sim 30 \mu \mathrm{m})$ long, with a well defined growth cone displaying characteristic microspikes and a triangular shape. A cell was considered labeled if it had as dense an overlay of grains as seen in Figure 1. Duplicate counts of at least 1000 cells were performed at all time points.

The following controls were performed to define the source of label seen in the autoradiographs. Previous work has shown that more than $98 \%$ of the trichloroacetic acid-precipitable $\left[{ }^{3} \mathrm{H}\right]$ thymidine present in the cells after a 2-hr exposure was in the form of DNA (Gunning et al., 1981). Furthermore, it was shown in this work that simultaneous exposure of cells to $\left[{ }^{3} \mathrm{H}\right.$ )thymidine and $1 \mu \mathrm{M}$ cytosine arabinoside for 2 hr resulted in no nuclear incorporation when assayed by autoradiography (data not shown).

Determination of nuclear DNA content. Isolated nuclei were used to measure DNA content because whole cells tend to form clumps of random size which are not amenable to accurate cytofluorography. The cytofluorographic protocol was essentially that of Krishan (1975) as modified by Deitch et al. (1982). Cells were grown for various length of time, with and without $\beta$-NGF, harvested, and resuspended in $5 \mathrm{ml}$ of a solution containing $0.1 \%$ NP-40 detergent, $75 \mu \mathrm{M}$ propidium iodide (Sigma), RNAse I (Worthington Biochemical Corp., Freehold, NJ; 1 Kunitz unit/ml), $5 \mathrm{mM} \mathrm{NaCl}$, and $3.4 \mathrm{~mm}$ trisodium citrate $(\mathrm{pH} 7.6)$ for $5 \mathrm{~min}$ at $37^{\circ} \mathrm{C}$. The suspension was centrifuged at $500 \times g$ for 10 min, and the pellet of stained nuclei was resuspended in the same solution to a final concentration of $1 \times 10^{5}$ nuclei $/ \mathrm{ml}$. This suspension was then analyzed on a Becton-Dickinson EPICS fluorescence-activated cell sorter (FACS) with Coulter electronics. Data were accessed either as frequency histograms of DNA content in arbitrary fluorescence units or as percentages of cells in the various stages of the cell cycle.

Percentages were determined using the EASY software package supplied with the instrument. Briefly, this analysis grouped cells in $\mathrm{G}_{1}(2 \mathrm{~N}), \mathrm{S}, \mathrm{G}_{2}+\mathrm{M}(4 \mathrm{~N})$, and $8 \mathrm{~N}$ bins according to their relative fluores cence or DNA content. An average of 10,000 nuclei were analyzed for each condition tested. Cell yields were slightly lower in the longer time points. Whether this was due to selective loss of process-bearing or process-free cells was not determined. One error in this analysis arises from the unusual poly jioid states of these cells. Normally, cells that have DNA values between a $2 \mathrm{~N}$ and $4 \mathrm{~N}$ amount are correctly scored as being in $\mathrm{S}$ phase of the cell cycle. However, if a tetraploid cell goes on to become octaploid, its cherrant $S$ phase will not be included with other $\mathrm{S}$ phase nuclei as its range of DNA values will fall between a $4 \mathrm{~N}$ and $8 \mathrm{~N}$ amount. Consequently, the value for cells in $\mathrm{S}$ phase is slightly underestimated.

In all analyses, cells were simultaneously measured for fluorescence and light scattering. This allowed us to measure the size of nuclei and also to determine the degree of clumping of nuclei. The homogeneity of the nuclei suspension was also confirmed visually under the microscope after toluidine blue staining, and in no instance did we see evidence for any clumping.

\section{Results}

$\left[{ }^{3} H\right]$ Thymidine incorporation in NGF-treated PC12 cells. The following experiment was designed to measure the percentage of NGF-primed and -unprimed PC12 cells which incorporated $\left[{ }^{3} \mathrm{H}\right]$ thymidine after a 2 -hr pulse, as an indicator of continued DNA synthesis. Unprimed cells plated out at low density with. out NGF exhibited the labeling indices (percentage of labcled cells) seen in Figure 2. After an initial increase at day 3 when $60 \%$ of the cells were labeled, the percentage of labeled cells dropped to $30 \%( \pm 3 \% \mathrm{SD})$ through day 7 . The initial jump to $60 \%$ was probably the result of a partial synchrony in cell division due to cell passage at the beginning of the experiment. For this reason subsequent experiments with NGF-induced cells were started 3 days after plating. Figure 2 also shows that changing the medium every other day had no stimulatory or inhibitory effect on the cells.

NGF treatment of PC12 cells resulted in the induction of neurites in $30 \%$ of the cells after 4 days and $60 \%$ after 6 days in culture (data not shown). Therefore, in order to examine the effects of NGF on DNA synthesis in differentiated, neuritebearing cells, primed cultures were assayed for $\left[{ }^{3} \mathrm{H}\right]$ thymidine uptake on days 3 to 7,12 , and 14 of NGF treatment. At each of these time points, cells with extensive neuritic processes were labeled after a 2 -hr pulse with $\left[{ }^{3} \mathrm{H}\right]$ thymidine. Figure 1 shows several examples of neurite-bearing cells heavily labeled over their nuclei. Figure 3 is a record of the labeling indices of the process-bearing, NGF-treated cells. On day 3 , when cells first start to show an appreciable number of processes, approximately $25 \%$ of the cells were labeled. By day 5 the percentage of labeled neurite-bearing cells dropped to $9 \%$, and this level of incorporation was maintained with little variability until day 14 when it decreased to $5.5 \%$. Clearly DNA synthesis was occurring at a time well after the elaboration of neurites.

It had been anticipated that the $40 \%$ of cells which were without neurites in these same cultures after 6 days of NGF treatment would be the source of the DNA synthesis seen by 

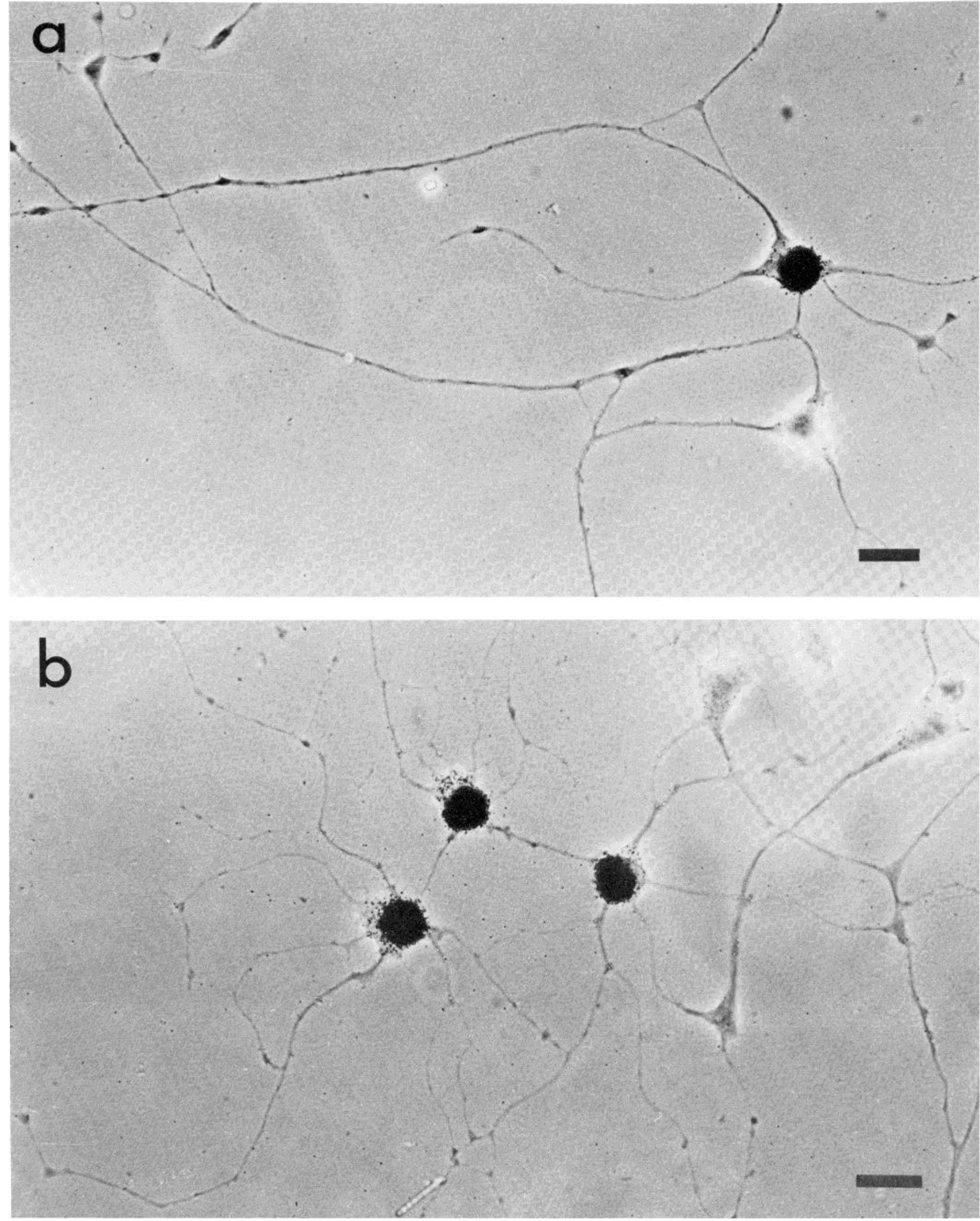

Figure 1. $\left[{ }^{3} \mathrm{H}\right]$ Thymidine-labeled process-bearing PC12 cells. In $a$, cells were grown for 10 days in NGF and on the 10 th day of incubation 2 $\mu \mathrm{Ci} / \mathrm{ml}$ of $\left[{ }^{3} \mathrm{H}\right]$ thymidine were added for $2 \mathrm{hr}$. The cells were then fixed and processed for autoradiography as described under "Materials and Methods." In $b$ cells were grown for the same length of time, but $\left[{ }^{3} \mathrm{H}\right]$ thymidine was added for $8 \mathrm{hr}$. In these developed autoradiographs, exposed silver grains appear as black dots, which can be seen here heavily concentrated over the nuclei of several cells. Only cells with such a dense overlay of grains were scored as labeled in the later studies. Scale bar $=10 \mu \mathrm{m}$. 
Figure 2. $\left[{ }^{3} \mathrm{H}\right]$ Thymidine incorporation by $\mathrm{PC} 12$ cells grown in culture without NGF. Confluent cells were passaged at low density and allowed to grow for 1 to 7 days with medium changes every other day $(\bullet)$ or without medium changes $(\nabla)$. At each time point, cells were given a $2-\mathrm{hr}$ pulse of $1 \mu \mathrm{Ci} / \mathrm{ml}$ of $\left[{ }^{3} \mathrm{H}\right]$ thymidine, processed for autoradiography, and, after a 2-week exposure, developed and scored for the percentages of cells with a dense overlay of autoradiographic grains. Error bars are the standard deviations from triplicate counts of duplicate experiments. Thirty percent of the cells in these control cultures are in S phase during any 2 -hr pulse after 3 days in culture.

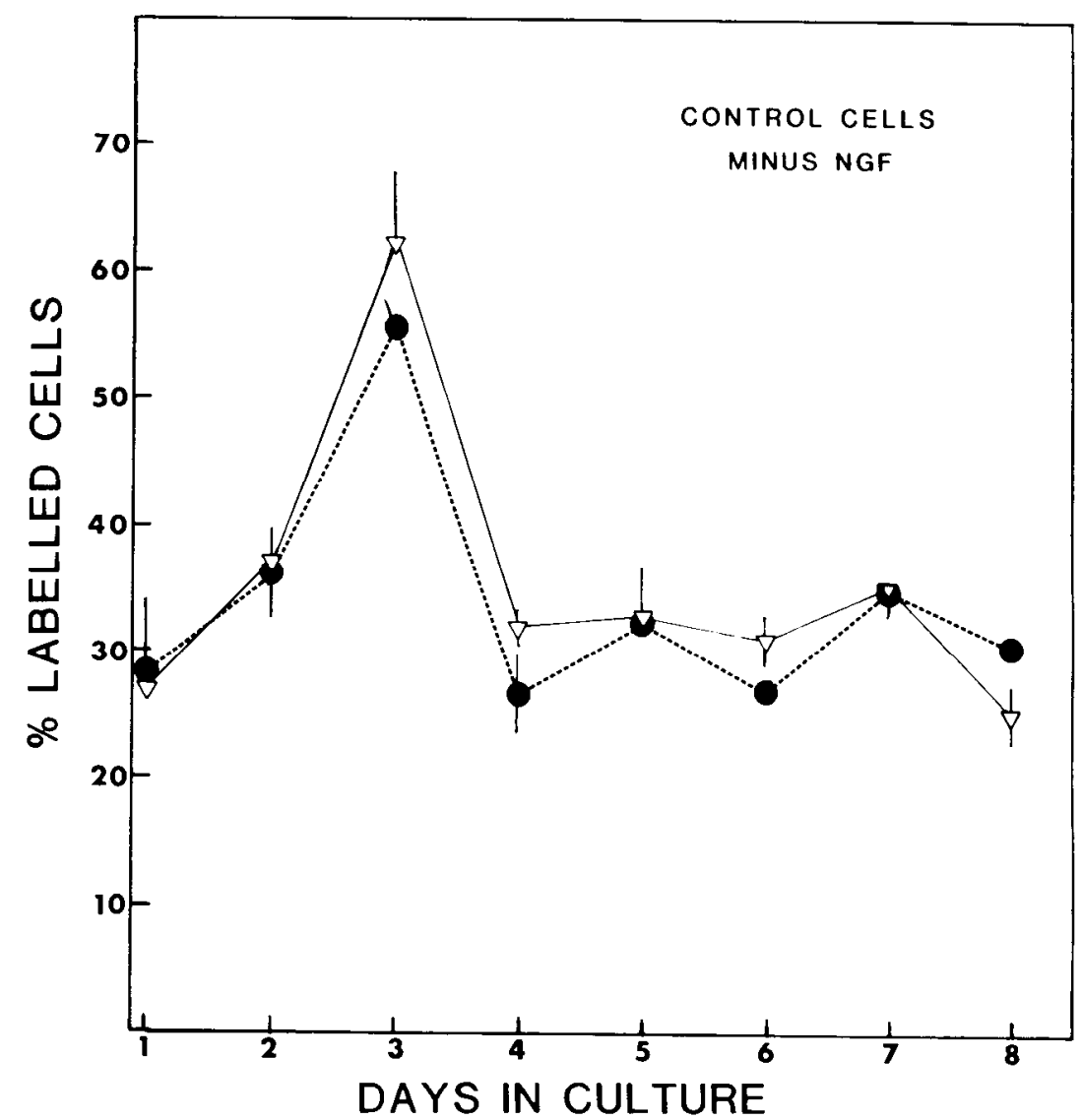

Figure 3. $\left[{ }^{3} \mathrm{H}\right]$ Thymidine incorporation by $\mathrm{PC} 12$ cells induced to differentiate with NGF. Parallel cultures were grown and tested for $\left[{ }^{3} \mathrm{H}\right]$ thymidine uptake as in Figure 1. Open triangles represent cultures with medium changes every other day; solid circles represent parallel cultures without medium changes. Three days after plating and every other day thereafter, $50 \mathrm{ng} / \mathrm{ml}$ of $\beta$-NGF were added. Data collection was begun on day 3 when cells first start to elaborate neurites. Data are expressed as the percentage of cells having neurites greater than two cell body diameters long with a well defined growth cone that had incorporated $\left[{ }^{3} \mathbf{H}\right]$ thymidine. Cells continue to synthesize DNA well after they have elaborated extensive neurites.

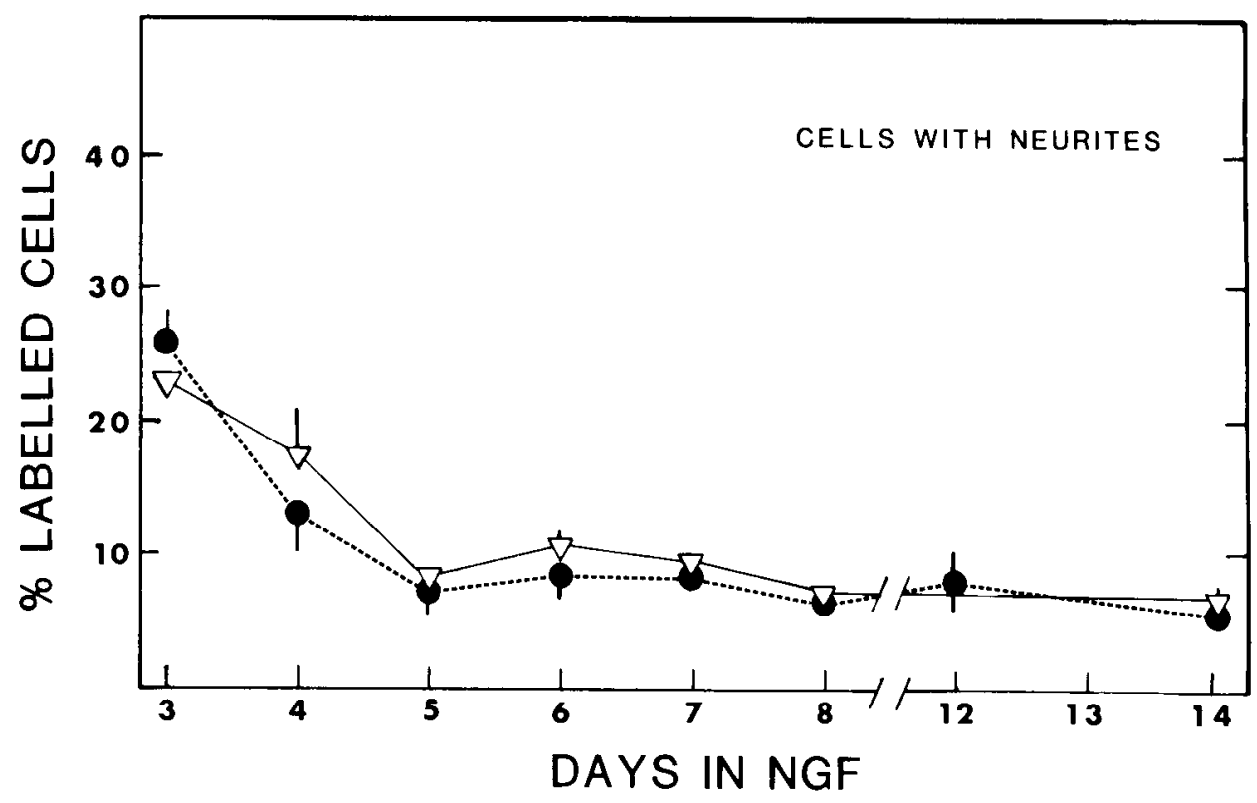

Gunning et al. (1981), and the process-bearing cells were blocked from mitotic activity solely as a result of the assembly of neurites. Instead, these undifferentiated cells had identical labeling indices from day 3 to day 7 of induction as morphologically differentiated cells (Fig. 4). NGF does not completely remove either of these populations from the cell cycle, yet it does have a true antimitogenic effect. The elaboration of neurites is not slowing DNA synthesis by secondarily removing components necessary for mitogenesis since DNA synthesis is reduced to the same degree in both process-bearing and nonprocess-bearing cells. It was not feasible to study cells after longer exposure since processes overlapped neighboring cells, obscuring the distinction between differentiated and undifferentiated cells.

In all of the above experiments only isolated cells were counted to ensure that a given neurite could be correctly assigned to the cell body of origin. This raised the possibility that cells in clumps, which represented as many as 20 to $30 \%$ of some cultures, might have different labeling indices. However, when the percentage of labeled cells in clumps was counted on days 3 to 7 , indices identical to those previously found for isolated cells were obtained. 


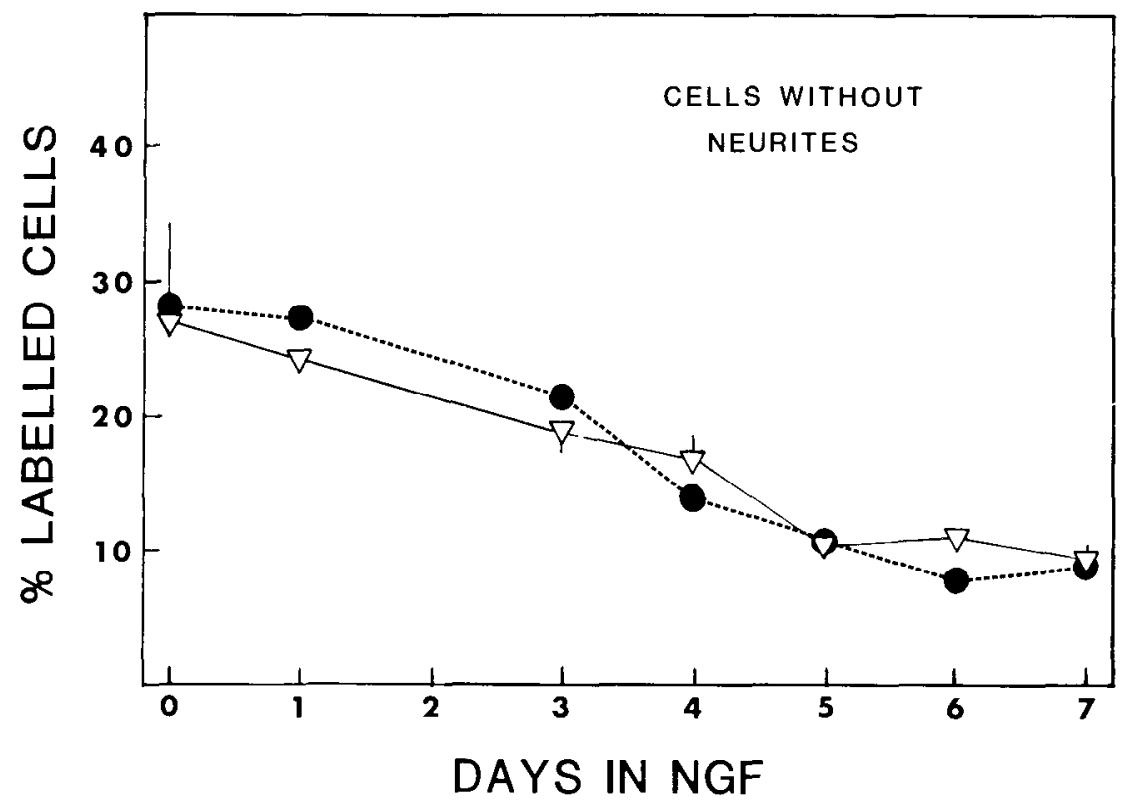

Figure 4. $\left[{ }^{3} \mathrm{H}\right]$ Thymidine uptake by NGFtreated PC12 cells lacking neurites. Growth conditions, induction, and scoring are as in Figure 3. Points here represent the percentage of cells with neurites less than one cell body diameter long that were labeled in the developed autoradiographs. Percentages are essentially identical to those found for neurite-bearing cells in the same cultures. Compare days 3 and 7 here with Figure 3.

Continuous labeling with $\left[{ }^{3} \mathrm{H}\right]$ thymidine. It is not possible to determine from the $2-\mathrm{hr}\left[{ }^{3} \mathrm{H}\right]$ thymidine pulse experiments what percentage of the total population of cells was still synthesizing DNA. The following procedure was designed to label all those cells which were still synthesizing DNA between days 8 and 13 of induction with NGF. $\left[{ }^{3} \mathrm{H}\right]$ Thymidine was added on day 8 of induction, and cells were fixed and processed at designated times after that. By $12 \mathrm{hr}$, about $20 \%$ of the cells were labeled (Fig. 5). Between 12 and $120 \mathrm{hr}$ there was a steady, linear increase in the percentage of labeled cells, such that by the 5th day of labeling, which corresponds to the 13th day of induction, nearly $70 \%$ of all cells were labeled.

No distinction between cells with and without processes was made in this continuous labeling study as it was not possible to judge when a given cell incorporated its label; i.e., before or after it had elaborated a process. Nor could any conclusion be drawn concerning the $30 \%$ unlabeled cells in this experiment. Equal numbers of process-bearing and process-free cells were found unlabeled, indicating that there was no bias in the labeling of quiescent or postmitotic differentiated cells. For technical reasons, longer labeling times were not feasible; therefore, it is not possible to say whether these unlabeled cells were truly postmitotic or whether the cell cycle had been lengthened to greater than 5 days. In all of the above studies the possibility existed that the $\left[{ }^{3} \mathrm{H}\right]$ thymidine incorporation was not due to DNA synthesis. To exclude this possibility, controls using 1 $\mu \mathrm{M}$ cytosine arabinoside were carried out, and incorporation of $\left[{ }^{3} \mathrm{H}\right]$ thymidine was found to be inhibited for at least 4 days. After 4 days of treatment, cytosine arabinoside was toxic to the cells. Such a toxic effect is normally seen in cells that are dividing, providing further evidence that DNA synthesis was indeed maintained in PC12 cells under the above conditions. The conclusion from these experiments is that the majority of cells treated with $\mathrm{NGF}$ for up to 12 days, regardless of their degree of morphological differentiation, still synthesize DNA.

$D N A$ content of isolated nuclei from NGF-treated cells. The observed uptake of $\left[{ }^{3} \mathrm{H}\right]$ thymidine probably reflects the synthesis of new copies of DNA. Although it is generally agreed that entry into $\mathrm{S}$ phase commits a cell to go through mitosis, the possibility exists that cells may become polyploid or binucleate. Less than $4 \%$ of the cells were binucleate after 14 days in NGF when examined by light microscopy and, because of cell overlap which obscures phase-bright cell boundaries, this number may be an overestimate. Therefore, to determine whether the cells were polyploid, Triton X-100-extracted nuclei were analyzed for DNA content using a FACS which, like a standard cytofluorograph, measures the amount of fluorescence (proportional to DNA content) of individual cells or nuclei. Figure 6 shows examples of this analysis conducted on cultures treated with $\mathrm{NGF}$ for $0,4,8$, and 14 days. As can be seen, there is a progressive shift in the frequency of greater than $2 \mathrm{~N}$ nuclei, so that by day 14 substantial $4 \mathrm{~N}$ and $8 \mathrm{~N}$ peaks appear.

The results of several cytofluorographic experiments are combined for comparison in Figure 7 . By 14 to 15 days in NGF, when the majority of cells had elaborated neurites, $55 \%$ of the nuclei had a $4 \mathrm{~N}$ (tetraploid) or more complement of DNA, compared to $15 \%$ in control or NGF-free cultures (Fig. 7). At this time, the number of $\mathrm{S}$ phase nuclei dropped from $22.5 \%$ in controls to about $6 \%$, in close agreement with the estimates from the thymidine incorporation studies (Figs. 3 and 4). Starting as soon as 4 to 5 days after NGF exposure, a fourth population of cells with an $8 \mathrm{~N}$ amount of DNA in their nuclei appeared which increased to nearly $8 \%$ of the total by 15 days (Fig. 7). In two longer-term experiments, after 20 days of NGF treatment a subpopulation of $16 \mathrm{~N}$ cells appeared (Figs. 7 and 8 ). The appearance of nuclei with $8 \mathrm{~N}$ and $16 \mathrm{~N}$ amounts of DNA were noteworthy for two reasons. First, it ruled out the possibility that the nuclei were clumping. If clumping was occurring, peaks should appear in the FACS analysis corresponding to odd amounts of DNA, e.g., $6 \mathrm{~N}$ or $10 \mathrm{~N}$ representing clumps of three or five nuclei. Second, the 2-, 4-, and 8-fold increase in the values for fluorescence indicated a true change in the ploidy or copies of the genome of the cells, rather than a linear increase in the DNA content of the cell. NGF treatment therefore increased the average amount of DNA per nuclei, reduced the number of $\mathrm{S}$ phase nuclei, and induced polyploidism in at least a subpopulation of cells. This increase was also reflected in an increase in nuclear size (Fig. $8 B$ ). Cells with more DNA had larger nuclei. Appropriate controls measuring the effect of medium changes were also carried out to determine whether artifacts produced by depletion of precusor pools necessary for normal cell division were present in these long-term studies. No change in the results was seen when medium along with fresh NGF was added to the cells every other day.

The dramatic rise in the $\mathrm{G}_{2}+\mathrm{M} / 4 \mathrm{~N}$ peak (shown in Fig. 7 ) is probably the result of the overlap of two cellular events: the formation of true tetraploid cells and the increased accumulation of $\mathrm{G}_{2}$ cells awaiting mitosis. The fact that $8 \mathrm{~N}$ cells even- 


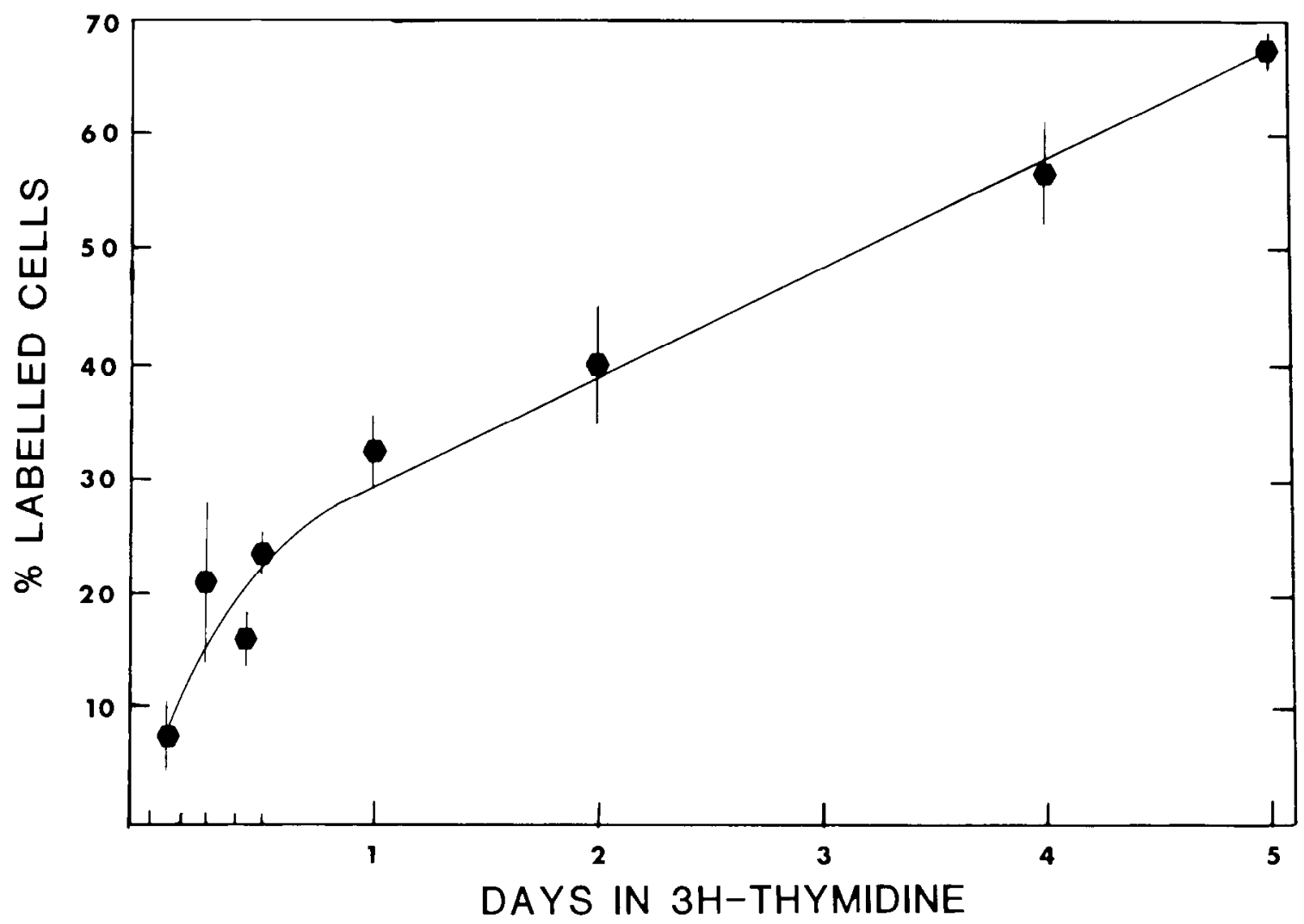

Figure 5. Continuous $\left[{ }^{3} \mathrm{H}\right]$ thymidine labeling of NGF-treated cultures. Growth and induction conditions were as in Figure 4. On day 8 of induction, $2 \mu \mathrm{Ci} / \mathrm{ml}$ of $\left[{ }^{3} \mathrm{H}\right]$ thymidine were added. At designated times after thymidine addition, cells were washed and processed for autoradiography. Data are expressed as the percentages of cells (both differentiated and undifferentiated) that were labeled in the autoradiographs. By day 5 of labeling, nearly $70 \%$ of the cells were labeled.

tually appear clearly demonstrates that there exists a true polyploid population of cells and not simply accumulated $\mathrm{G}_{2}$ cells awaiting division. What is difficult to determine is the percentage of the $4 \mathrm{~N}$ peak that these truly polyploid cells represent.

The evidence for the presence of a population of $G_{2}$ and $M$ cells preparing for normal division is provided by the observation of a plateau in the number of $2 \mathrm{~N}$ cells in spite of the observed continued DNA synthesis in more than $5 \%$ of the cells at any one time. The possibility that the neurite-bearing cells in the population are dividing cannot be addressed in these cytofluorographic studies. Despite identical $\left[{ }^{3} \mathrm{H}\right]$ thymidine labeling indices for the morphologically differentiated and undifferentiated cells, the two populations may vary in their ability to divide.

In an attempt to resolve this issue, time lapse films of NGFtreated cultures, recording days 9 through 13 of treatment, were made. After $400 \mathrm{hr}$ of filming more than 200 cells, only three examples of dividing, differentiated cells were seen (data not shown). Furthermore, although films were biased toward recording fields of differentiated cells, no examples of processfree cells dividing were found. The films show that, even though division by neurite-bearing $\mathrm{PC} 12$ cells is infrequent, it does occur and therefore may help to explain the persistance of a population of $2 \mathrm{~N}$ cells despite the ongoing DNA synthesis.

\section{Discussion}

The data reported here show by a variety of techniques that PC12 cells treated with NGF for up to 14 days in culture continue to synthesize DNA and either divide or become polyploid. This is true for both process-bearing and non-processingbearing cclls. The non process bearing cells comprise roughly $40 \%$ of our cultures (Gunning et al., 1981), and these are commonly thought to be unresponsive to the application of NGF. Our $\left[{ }^{3} \mathrm{H}\right]$ thymidine studies indicate that in fact $\mathrm{NGF}$ does exert a similar antimitogenic effect on cells both with and without neurites, indicating that, in at least one sense, these cells are responsive. Conversely, the induction of neurite outgrowth by NGF need not be associated with a cessation of DNA synthesis.

What is the fate of this newly synthesized DNA? The cytofluorograph studies show that NGF treatment stimulates an increase in the average amount of DNA per cell, so that by 14 days, only $43 \%$ of the cells remain diploid (compared to $60 \%$ diploid cells in cultures without NGF), whereas the rest have at least twice their normal complement of DNA. As noted earlier, the tetraploid cells could be in either of two states, $\mathrm{G}_{0}$ or $\mathrm{G}_{1}$, and therefore, could be truly tetraploid or in $\mathrm{G}_{2}$ awaiting division. The present data do not distinguish between these two possibilities for either neurite-bearing or neurite-free cells. The question could be approached by either time lapse cinematography or microcytofluorimetry of whole cells. In the time lapse studies it was observed that, in 200 cells treated with NGF for 8 to 13 days, only 3 cells with neurites and none without neurites went through cell division, thus supporting the idea that most of the DNA-synthesizing $\mathrm{PC} 12$ cells are becoming polyploid. If only a few cells are dividing, then some other explanation must exist for the plateau in the number of $2 \mathrm{~N}$ cells observed despite the persistent DNA synthesis in $5 \%$ of the cells during any 2 -hr period and in $70 \%$ of the cells over a 5 -day period. It may be that some polyploid cells are differentially lost, thereby masking any real decrease in the absolute number of $2 \mathrm{~N}$ cells. Since this was not determined, the present study can neither conclude nor exclude the possibility that the mitotic activity represented by ongoing DNA synthesis actually is associated with normal division of NGF-treated cells. Far 


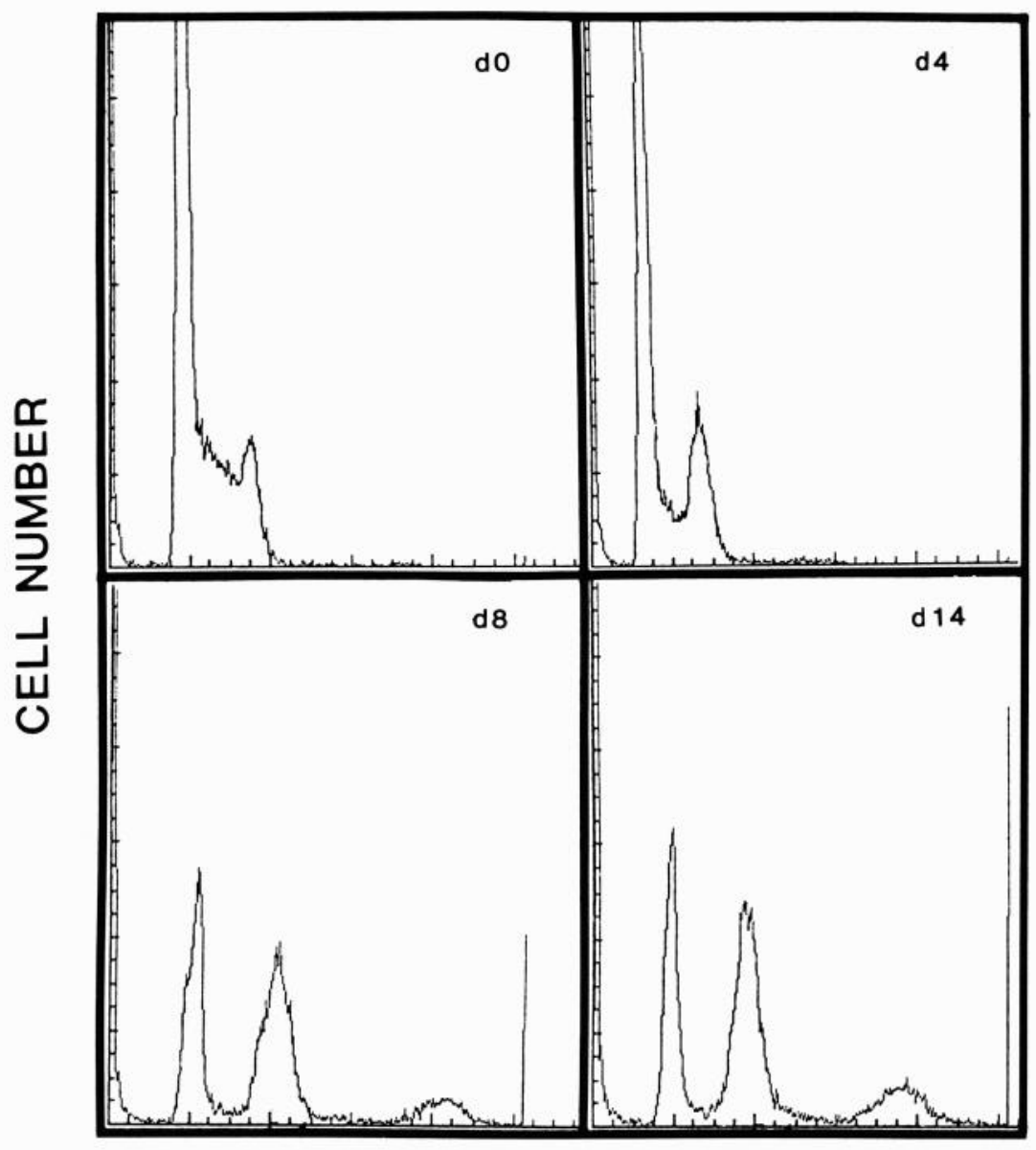

\section{CHANNEL NUMBER (DNA)}

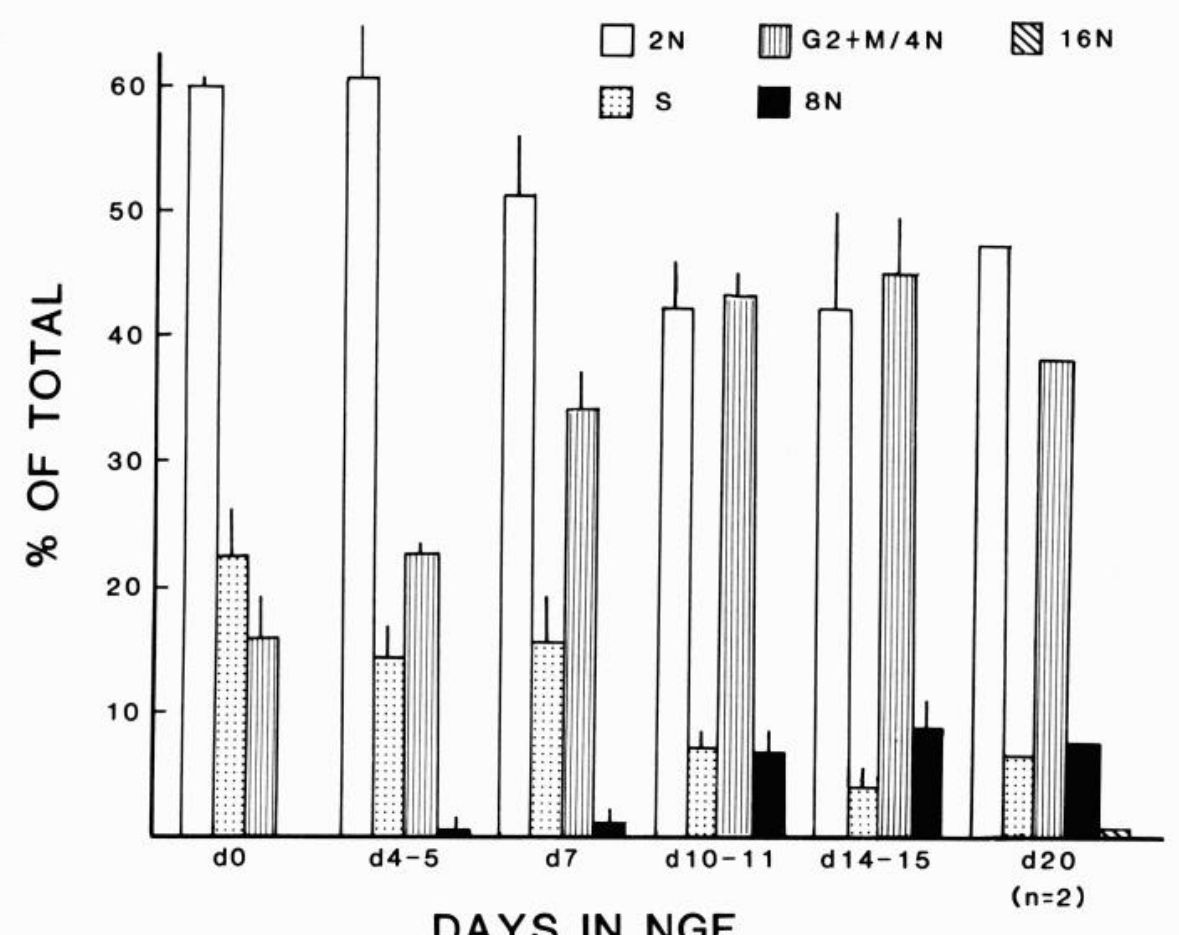

Figure 6. Samples of cytofluorograph-derived histograms measuring the change in DNA content of isolated PC12 nuclei treated with NGF. With increasing time in NGF the number of $2 \mathrm{~N}$ and $\mathrm{S}$ phase nuclei decreased, whereas the percentage of $\mathrm{G}_{2}+\mathrm{M} / 4 \mathrm{~N}$ and $8 \mathrm{~N}$ cells increased. Cells were grown as described under "Materials and Methods" with NGF treatment for the designated lengths of time, then harvested into a detergent solution to extract the nuclei, which contained the DNA stain propidium iodine (see "Materials and Methods"). The resultant suspension was analyzed on a per particle or nuclei basis for the amount fluoresced. Each run here represents 10,000 nuclei. The samples shown here were without medium changes. Medium changes, however, had no effect on the observed distribution. See Figure 7 for pooling of multiple trials.
Figure 7. Frequency histograms of the DNA distribution in isolated nuclei of NGF-treated cells. The decreasu in $2 \mathrm{~N}$ and $\mathrm{S}$ phase nuclei is offset by the increase in $\mathrm{G}_{2}+\mathrm{M} / 4 \mathrm{~N}$ and $8 \mathrm{~N}$ cells. Cells were grown and analyzed as in Figure 6. Each time point represents the average of at least four separate, duplicate runs of 10,000 nuclei (with the exception of $d 20$ where $n=2$ ). Determinations of $2 \mathrm{~N}, \mathrm{~S}$, $\mathrm{G}_{2}+\mathrm{M} / 4 \mathrm{~N}$, and $8 \mathrm{~N}$ populations are described under "Materials and Methods." Polyploid cells are forming as a result of NGF treatment. 
Figure 8. Frequency histograms of one long-term (20day) culture of NGF-treated cells in which a subpopulation of $16 \mathrm{~N}$ cells appeared. On the right, this same group of cells was simultaneously analyzed for DNA content as a function of nuclear diameter (as derived from lightscattering measurements). As the ploidy or DNA content of the nucleus increases, there are corresponding increases in nuclear volume.
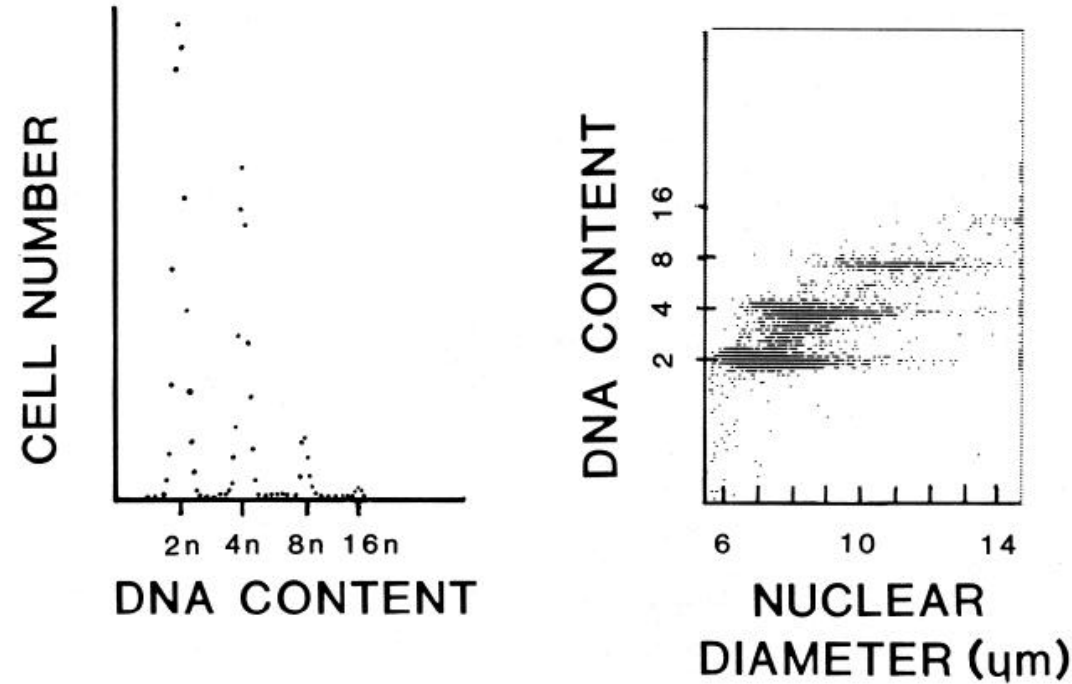

more certain is the finding that this DNA synthesis results in the formation of polyploid $4 \mathrm{~N}, 8 \mathrm{~N}$, and $16 \mathrm{~N}$ cells.

The possibility that dividing cells exist in these cultures is not necessarily in conflict with the finding of a plateau in cell number (Greene and Tischler, 1976; Dichter et al., 1977) and DNA content (Gunning et al., 1981) seen after NGF treatment. Instead, it is likely to be the consequence of the continued turnover of cells. This could occur either through cells dissociating from the culture dish and being subsequently removed in medium changes, or merely through the death and eventual degradation of the cells. Division, both of differentiated and undifferentiated cells, would then maintain a constant number of cells. That such an equilibrium exists is supported by two other lines of evidence. First, by including the medium in their assay of DNA content in NGF-treated cultures, Goodman et al. (1979) found no plateau of DNA content with increased time in NGF. Second, cell viability measurements of PC12 cells generally indicate that greater than $5 \%$ of the cells at any one time of NGF induction fail to exclude trypan blue (Landreth and Shooter, 1980, and this study). Taken together, these two observations suggest that growth curves in this cell line do not give a reliable measure of cell proliferation.

The persistent DNA synthesis in these extensively differentiated PC12 cells may merely reflect retained neoplastic properties since these cells are tumor derived. Yet several examples of continued DNA synthesis in non-neoplastic, differentiated nerve cells have been seen, casting some doubt on the dogma that DNA synthesis is incompatible with nerve cell differentiation (see Grobstein, 1959; Angevine, 1970; Rakic, 1973). In Aplysia, a neuron exists which is $75,000 \mathrm{~N}$ (Coggeshall et al., 1970; Lasek and Dower, 1971), despite having extensive connections and cytochemically differentiated properties. The case for polyploid cells in vertebrate neurons is less dramatic, but no less significant. Cells with a DNA content of $3 \mathrm{~N}$ and $4 \mathrm{~N}$ exist in the CNS (Herman and Lapham, 1968; Lapham, 1968; Billings and Swartz, 1969; Bregnard et al., 1975, 1977; Bohm et al., 1981), and $4 \mathrm{~N}$ as well as $8 \mathrm{~N}$ cells exist in the PNS (Kusch and Yarygin, 1965). $\left[{ }^{3} \mathrm{H}\right]$ Thymidine uptake in putative neurons in layer 4 of 90 -day-old cat visual cortex has been reported by Kaplan (1981, 1984). Moreover, several authors (Stillwell et al., 1973; Cone and Cone 1976, 1978) have been able to induce DNA synthesis in CNS neurons in vivo by sustained depolarization of the cells. Of particular relevance to the present work is the discovery that certain cells derived from the neural crest continue to synthesize DNA after the acquisition of neuronal properties. $\left[{ }^{3} \mathrm{H}\right]$ Thymidine uptake by cytochemically differentiated embryonic rat and chick sympathoblasts have been re- ported by Cohen (1974), Rothman et al. (1978, 1980), and Teitelman et al. (1981). More noteworthy is the observation that nearly $10 \%$ of the pheochromocytes in 2-week-old rat adrenal medulla, with detectable stores of catecholamines, can be radiolabeled after a $1-\mathrm{hr}$ pulse with $\left[{ }^{3} \mathrm{H}\right]$ thymidine (Jurecka et al., 1978).

As is evident from the current study, thymidine uptake and subsequent DNA synthesis is not proof of continued cell division. In fact, the findings that polyploid cells are present in the PNS (see above) indicate that $\left[{ }^{3} \mathrm{H}\right]$ thymidine incorporation (e.g., Kaplan, 1981) may represent the formation of polyploid cells. However, these reports clearly indicate that there is at least maintained DNA synthesis in subpopulations of mature nerve cells. The significance of this phenomenon is not clear. Continued division by cells with extensive processes and connections would seem to be very inefficient for a developing organism since it would necessitate the depolymerization of cytoskeletal elements and the subsequent retrieval of neurites. The formation of polyploid neurons may be a solution to this dilemma. The elaboration of neurites and the corresponding stabilization of microtubules within them could prevent a cell from undergoing either cytokinesis or karyokinesis but would not prevent the duplication of its genome. It cannot be ruled out in the present study that the population of $40 \%$ or so cells without neurites can divide-albeit at a reduced rate, whereas most of the neurite-bearing cells are becoming polyploid. If such were the case, however, long-term cultures would eventually be taken over by non-neurite-bearing cells, an occurrence not known to happen, at least within the time scale under study here.

The present study shows that NGF acts as an antimitogen, although not a complete one. $\mathrm{PC} 12$ cells induced to sprout neurites by the addition of NGF continue to synthesizes DNA. The persistent DNA synthesis seen here suggests that NGF in a developing animal cannot by itself block mitosis of neuroblasts, but rather may act in concert with other factors and signals to fully inhibit division. It is conceivable that successful innervation of a target by a nerve cell is one such signal. In this context, it would be useful to know whether synapse formation-absent in our cultures-could aid in the complete removal of these cells from all cell cycle activity.

\section{References}

Angevine, J. B. (1970) Critical cellular events in the shaping of neural centers. In The Neurosciences Second Study Programs, F. O. Schmitt, ed., pp. 62-82, Rockefeller University Press, New York.

Billings, S., and F. J. Swartz (1969) DNA content of Mauthner cell 
nuclei in Xenopus laevis: A spectrophotometric study. Z. Anat. Entwicklungsgesch. 129: 14-23.

Bregnard, A., A. Knusel, and C. C. Kuenzle (1975) Are all the neuronal nuclei polyploid? Histochemistry 43: 59-61.

Bregnard, A., C. C. Kuenzle, and F. Ruch (1977) Cytophotometric and autoradiographic evidence for post-natal DNA synthesis in neurons of the rat cerebral cortex. Exp. Cell Res. 107: 151-157.

Bohm, N., B. Kroner, and E. Kaiser (1981) Cytophotometric evidence of non S-phase extra-DNA in human neuronal nuclei. Cell tissue Kinet. 14: 433-444.

Coggeshall, R. E., B. A. Yaksta, and F. J. Shwartz (1970) A cytophotometric analysis of the DNA in nucleus of giant cell, R-2 in Aplysia. Chromosoma 32: 205-212.

Cohen, A. M. (1974) DNA synthesis and cell division in differentiating avian adrenergic neuroblasts. In Dynamics of Degeneration and Growth in Neurons, K. Fuxe, L. Olsen, and Y. Zotterman, eds., pp. 359-370, Pergamon Press, New York.

Cone, C. D., and C. M. Cone (1976) Induction of mitosis in mature neurons in central nervous system by sustained depolarization. Science 192: 155-157.

Cone, C. D., and C. M. Cone (1978) Evidence of normal mitosis with complete cytokinesis in central nervous system neurons during sustained depolarization with ouabain. Exp. Neurol. 60: 41-55.

Deitch, A. D., H. Law, and R. D. White (1982) A stable propidium iodide staining procedure for flow cytometry. J. Histochem. Cytochem. 30:967-972.

Dichter, M. A., A. S. Tischler, and L. A. Greene (1977) Nerve growth factor-induced increase in electrical excitability and acetylcholine sensitivity of a rat pheochromocytoma cell line. Nature 268: 501504.

Garrels, J. E., and D. Schubert (1979) Modulation of protein synthesis by nerve growth factor. J. Biol. Chem. 254: 7978-7985.

Goodman, R., C. Chandler, and H. R. Herschman (1979) Pheochromocytoma cell lines as models of neuronal differentiation. Cold Spring Harbor Conf. Cell Proliferation 6: 653-669.

Greene, L. A. (1978) Nerve growth factor prevents the death and stimulates the neuronal differentiation of clonal $\mathrm{PC} 12$ pheochromocytoma cells in serum-free medium. J. Cell Biol. 78: 747-755.

Greene, L. A., and A. S. Tischler (1976) Establishment of a noradrenergic clonal line of rat adrenal pheochromocytoma cells which respond to NGF. Proc. Natl. Acad. Sci. U. S. A. 73: 2424-2428.

Grobstein, D. (1959) Differentiation of vertebrate cells. In The Cell, J. Brachet, and A. Mirsky, eds., Vol. 1, pp. 437-497, Academic Press, Inc., New York.

Gunning, P. W., G. E. Landreth, P. Layer, M. Ignatius, and E. M. Shooter (1981) Nerve growth factor-induced differentiation of PC12 cells: Evaluation of changes in RNA and DNA metabolism. J. Neurosci. 1: 368-379.

Hatanaka, H., V. Otten, and H. Thoenen (1978) Nerve growth factormediated selective induction of ornithine decarboxylase in rat pheochromocytoma: A cyclic AMP-independent process. FEBS Lett. 92: 313316 .
Herman, C. J., and L. W. Lapham (1968) DNA content of neurons in the cat hippocampus. Science 160:537.

Jurecka, W., H. Lassmann, and H. Horander (1978) The proliferation of adrenal medullary cells in newborn and adult mice. A light microscopic autoradiographic study. Cell Tissue Res. 189: 305-312.

Kaplan, M. S. (1981) Neurogenesis in the 3-month-old rat visual cortex. J. Comp. Neurol. 195: 323-338.

Kaplan, M. S., and D. H. Bell (1984) Mitotic neuroblasts in the 9-dayold and 11-month-old rodent hippocampus. J. Neurosci. 4: 14291441.

Kopriwa, B. M., and L. P. Leblond (1962) Improvement in the coating technique of radioautography. J. Histochem. Cytochem. 10: 269-284.

Krishan, A. (1975) Rapid flow cytofluorometric analysis of mammalian cell cycle by propidium iodide staining. J. Cell Biol. 66: 188-193.

Kusch, A. A., and V. N. Yarygin (1965) Polyploid mono- and binucleate neurons in the upper cervical ganglion of rabbit. Tsitologiya 7: 228233.

Landreth, G. E., and E. M. Shooter (1980) Nerve growth factor receptors on PC12 cells: Ligand-induced conversion from low- to highaffinity states. Proc. Natl. Acad. Sci. U. S. A. 77: 4751-4755.

Lapham, L. W. (1968) Tetraploid DNA content of Purkinje neurons of human cerebellar cortex. Science 159: 310-312.

Lasek, R. J., and W. J. Dowder (1971) Aplysia californica: Analysis of nuclear DNA in idividual nuclei of giant neurons. Science 172: 278280.

Rakic, P. (1973) Kinetics of proliferation and latency between final cell division and onset of differentiation of cerebellar stellate and basket neurons. J. Comp. Neurol. 147: 523-546.

Rothman, T. P., M. D. Gershon, and H. Holtzer (1978) The relationship of cell division to the acquisition of adrenergic characteristics by developing sympathetic ganglion cell precursors. Dev. Biol. 65: 332341.

Rothman, T. P., L. A. Specht, M. D. Gershon, T. H. Joh, G. Teitelman, V. M. Pickel, and D. J. Reis (1980) Catecholamine biosynthetic enzymes are expressed in replicating cells of the peripheral but not the central nervous system. Proc. Natl. Acad. Sci. U. S. A. 77: 62216225 .

Schubert, D., S. Heinemann, and Y. Kidokoro (1977) Cholinergic metabolism and synapse formation by a rat nerve cell line. Proc. Natl. Acad. Sci. U. S. A. 74: 2579-2583.

Smith, A. P., S. Varon, and E. M. Shooter (1968) Multiple forms of the nerve growth factor protein and its subunits. Biochemistry 1 : 3259-3268.

Stillwell, E. F., C. M. Cone, and C. D. Cone (1973) Stimulation of DNA synthesis in CNS neurons by sustained depolarization. Nature 245 : $110-111$.

Teitelman, G., M. D. Gershon, T. P. Rothman, T. H. Joh, and D. J. Reis (1981) Proliferation and distribution of cells that transiently express a catecholaminergic phenotype during development in mice and rats. Dev. Biol. 86: 348-355.

Thoenen, H., and Y. A. Barde (1980) Physiology of nerve growth factor. Physiol. Rev. 60: 12841334. 